\title{
Spring in the Valley
}

By R. C. Mackenzie

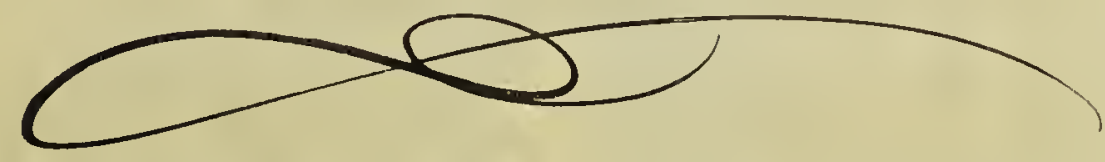

The most important event of spring, to naturalists who live in Regina, is our first visit to the Qu' Appelle Valley. It usually comes in April, and marks the opening of what you might call our field season. Pasque Flowers (Prairie Crocus) are lifting their purple blooms above the sere grass at that time. Of course, we go again later to see whole hillsides whiten with the silver-white blossoms of Saskatoon Bush and to enjoy the fragrance of scented cherry blossoms. Then in early June to see the hills come to glowing colored life, with the delicate, wax-like, gold tinted petals of Prickly Pear Cactus, that porcupine of plant life that holds on its thickened pear-shaped stems, ( for what appear to be leaves are stems in the cacti family), one of our most beautiful flowers. In the same season the smaller Ball Cactus puts forth its purple stars. Symmetrically perfect amethyst beauties, growing in starlike constellations on the green hillslopes.

A spring visit to the valley is never complete without at least one afternoon spent in Cately's Coulee. This deep and surprisingly narrow ravine is bounded to westward by a sheer cliff more than two hundred feet high. Many years ago Cree and Assiniboin hunters built at the top of this cliff, where dark Ground Cedar patches overhang the precipice, a buffalo pound, into which they herded thousands of the great beasts, forcing them to leap to their death in the depths below. I do not know if it is due to the long since rotted bones of Buffalo herds, or to the abundant water supplied by the little creek in the valley and the many tiny cataracts and marshy rivulets that des-

cend from the great spring that flows from the ground near the top of the east hill, but this is certain; in few other places in this province does the North- ern Bog Violet bloom in greater abundance. There are violet patches, yards in width in the marshy ground, violets growing among stones, spray moistened by tiny waterfalls, violets in the long grass, by every mossy tree trunk, and by every mossy stone. On the higher ground White Canada Violets grow, mixing with Wood Anemones, Blue Sand Violets climb the sandy cutbanks, and Yellow Violets bloom on the dry hills above.

Black Poplars, tall and balsam scented, edge the creek, Willows, White and Black Birch, tangled thorny rosebushes and red-stemed, white flowered dogwood almost overgrow the narrow winding path, that climbing abruptly and descending steeply, follows the rockstrewn bed of the little creek, and branching off at one of the small tributaries follows this miniaturewaterway through the thick White Birch woods cover that the steep east hill, merging into Ash, Elm, and Maple woods, that in turn give way to hawthorn and Wolf Willow where the top of the slope edges the high dry plains.

There are many birds here, Robins, Wrens, and Song Sparrows, Flickers, Woodpeckers, Fastern Bluebirds, and sometimes Mountain Bluebirds too. Zones of flora and fauna overlap in this part of the Qu'Appelle Valley, for where the Eastern Bluebird meets the Bluebird of the mountains, Western Black River Birch meets the Elm and Ash woods of the east, reaching almost their fartherest west in this latitude. The bog-loving low bush Cranberry, the Bunch Berry, the showy Ostrich Ferm and the small delicate Fragile Fern, grow in these collees, often only a few hundred feet from Sagebrush, Ground Cedar, and the cactus of the semi-arid plains. 